\title{
As origens da assistência psiquiátrica no Brasil: o papel das santas casas
}

Entre as inúmeras irmandades que se instalaram no Brasil, desde o denominado descobrimento, a mais importante foi a Misericórdia.

Inspirada no modelo da Casa-mãe de Lisboa, fundada em 1498 por iniciativa real, a Irmandade de Misericórdia chega ao Brasil em 1543 com a fundação da Santa Casa de Santos, por Braz Cubas. Em seguida espalhou-se, criando vários hospitais e se constituindo na base assistencial hospitalar da colônia, além de servir, mais tarde, como espaço de treinamento para a formação dos primeiros médicos brasileiros.

Os fundos para a sustentação das suas atividades sempre vieram de donativos sociais e subvenções do Estado. De uma maneira geral, as Misericórdias mantiveram, ao longo da sua história no Império colonial português, padrões surpreendentemente elevados de honestidade e de eficiência na administração dos programas assistenciais. ${ }^{1}$

A partir do século XVIII já se tem notícia de que a Santa Casa da Bahia reservava acomodações para doentes mentais e que esses espaços eram conhecidos como "casinha de doudos".

A Santa Casa de São Paulo, na primeira metade do século XIX, chegou a alugar um imóvel exclusivo para cuidar dos alienados. ${ }^{3}$

Também a Santa Casa do Rio de Janeiro acolheu alienados até a instalação do Hospício de Pedro II, em 1852, quando então a Mesa foi designada para administrá-lo, por meio de lei imperial. ${ }^{4}$

E vem, da Santa Casa de São João Del Rey, Minas Gerais, datado de 1817, o primeiro registro de internação de doente mental no Brasil. ${ }^{5}$

\section{Referências}

1. Boxer CR. O império colonial português (1415-1825). Lisboa, Portugal: Edições Setenta; 1969.

2. Mesgravis L. A Santa Casa de Misericórdia de São Paulo (1559-1884). São Paulo, Brasil: Conselho Estadual de Cultura; 1976.

3. Idem, ibidem pgs. 196-198.

4. Decreto imperial no. 1077. Colecção de leis do império. Rio de Janeiro, Brasil: Imprensa Nacional; 1852.
As Santas Casas, mesmo criticadas por vários autores no que se refere à forma dos cuidados oferecidos aos doentes mentais confinados ou encarcerados, não tiveram, a bem da verdade, ao longo do século XIX, modelos assistenciais muito diferentes no resto do mundo nos quais pudessem se espelhar.

Problema maior ocorreu na segunda metade do século XX no Brasil, quando as Santas Casas já estavam fora do cenário assistencial psiquiátrico, e modelos assistenciais mais evoluídos já se espalhavam em algumas partes do mundo. Quem viveu viu, sobretudo nas décadas de 1970 e 1980, hospitais públicos e privados encarcerarem doentes mentais sob o pretexto de tratamento, e boa parte deles com escusos fins lucrativos. $^{6}$

Um viajante francês que percorreu o Brasil na primeira metade do século XIX é exemplar para definir o papel da Misericórdia no Brasil, quando relata que "existe em São Paulo um hospício para o recolhimento dos infelizes atingidos pela morféia, horrorosa enfermidade, que só a caridade pode impedir de ser olhada sem enorme repugnância". ${ }^{7}$

Além de exemplar, a observação acima, de Saint Hilaire, é de grande valor histórico para a psiquiatria brasileira, porque reafirma que o hospício, no Brasil, serviu como espaço exclusivo aos hansenianos antes dos doentes mentais.

Gabriel Figueiredo

Departamento de Neuropsiquiatria da FCM/PUC, Campinas 